BIOKEMISTRI 17(2):157-163 (Dec 2005)

Available online at http://www.bioline.org. br/bk.

Abstracted online at www.ajol.info/journals/biokem

Printed in Nigeria

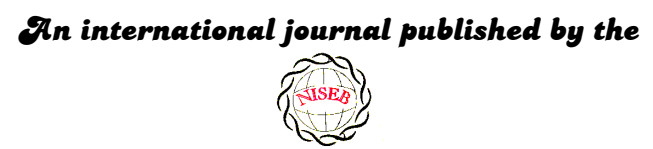

Tigerian \&ociety for \&ิxperimental \&iology

\title{
Sub-chronic effect of Rambo insect powder contaminated diet on superoxide dismutase (SOD) activity in Wister albino rats
}

\author{
Olawale OTITOJU* \\ Postgraduate Research Laboratory, Department of Biochemistry University of Nigeria, Nsukka, \\ Enugu State, Nigeria
}

Received 9 July 2005

MS/No BKM/2005/032, ( 2005 Nigerian Society for Experimental Biology. All rights reserved.

\begin{abstract}
Studies of superoxide dismutase (SOD) induction in rats exposed to locally produced insecticide, "Rambo" of which the active chemical compound is permethrin $(0.6 \% \mathrm{w} / \mathrm{w})$ was performed. The rats were divided into three groups of five rats per cage. Each group of rats was fed with normal diet contaminated with $1 \%, 5 \%$ and $10 \%(\mathrm{w} / \mathrm{w})$ of the insecticide respectively. The control group was fed normal diet. The effect of insecticide at various concentrations on superoxide dismutase (SOD) activity in the blood plasma was not significantly different $(\mathrm{P}>0.05)$ in the newly weaned rats (NWR). However, in the middle-aged rats (MAR) and aged rats (AR) groups, the results were significantly different $(\mathrm{P}<0.05)$ against the parallel controls. Comparison of the effect of the insecticide on SOD induction at various concentrations among the groups based on age difference showed significantly different result $(\mathrm{P}<0.05)$, especially among the groups fed with $10 \%(\mathrm{w} / \mathrm{w})$ of the insecticide in the diet. Results of this study show that in non-target organisms "Rambo" insect powder may induce superoxide dismutase activity thus suggesting oxidative-stress related toxicity.
\end{abstract}

Key words: Superoxide dismutase, permethrin, Rambo insect powder

*Present address: Department of Biochemistry, Kogi State University Anyigba, Kogi State, Nigeria. E-mail: otitojuolawale@yahoo.com, Tel: +234 8033622480 


\section{INTRODUCTION}

One of the greatest challenges to humanity today is the endangering of living things as a result of environmental pollution by various xenobiotics (pesticides). The adverse effect of some pesticides has necessitated legislation in certain countries against potentially damaging ones. Such countries include the United States of America, Sweden and United Kingdom ${ }^{1}$. However, in most developing countries, pesticides are still being used without assessing their effects on human health, for example immune response $^{1}$, carcinogenic effects ${ }^{2}$, neurological actions and alteration of reproduction $^{3}$. The use of pesticides in agriculture and domestic pest control has elicited different kinds of diseases or responses in those exposed to them, particularly farmers. These hazards go beyond farming community because pesticide residues are found in food. They also contaminate soil and water supplies.

To estimate the biological danger, knowledge of the harmful effects of pollutants is necessary ${ }^{4}$. These harmful effects may occur directly as a result of pesticides being converted to free radicals or via the formation of superoxide as a by-product of their metabolism ${ }^{5}$. The repertoires to counteract the potentially hazardous reactions initiated by oxygen metabolites include all levels of protection, prevention, interception and repairs. It comprises non-enzymatic and enzymatic systems. The enzymes involved in antioxidation are the superoxide dismutase, glutathione peroxidase and catalases ${ }^{6}$. Superoxide dismutase (SOD) catalyses the destruction (dismutation) of superoxide free radical ions. These ions are believed to be responsible for lipid peroxidation and peroxidative haemolysis of erythrocytes. The action of SOD therefore results in the protection of the biological integrity of cells and tissues against the harmful effects of superoxide free radicals ${ }^{7}$. To ameliorate the damage caused by the hydroxyl radical formed from superoxide radicals and hydrogen peroxide, organisms have evolved mechanisms to regulate the concentrations of the two reactants. SOD is an important isoenzyme functioning as superoxide radicals' scavenger in the living organisms ${ }^{8}$. It is an important enzyme family in living cells for maintaining normal physiological conditions and coping with stress ${ }^{9}$.

The increased use of pesticides has led to potentially adverse effects in humans and animals ${ }^{10}$. In this study, sub-chronic effect of Rambo insect powder contaminated diet on superoxide dismutase (SOD) activity in Wister albino rats was investigated.

\section{MATERIALS AND METHODS}

\section{Test sample}

The test sample for the study is a commercially available insecticide, "Rambo", reportedly containing $0.60 \%$ permethrin. Rambo insect powder is the product of Gongoni Co. Limited, 89A Sharade Industrial Estate, Phase III, Kano Nigeria. Test sample was bought from Ogige market, Nsukka.

\section{Formulation of contaminated diets}

Commercial animal feed, Top feed was contaminated with the insecticide by weighing out a definite amount of the feed and then mixing with the "Rambo" insect powder to give a ratio of $1 \%, 5 \%$, and $10 \%(\mathrm{w} / \mathrm{w})$ contamination. Normal uncontaminated feed was used for control.

\section{Experimental animals}

Wister albino rats weighing between $120-720 \mathrm{~g}$ were obtained from the Faculty of Veterinary Medicine, University of Nigeria, Nsukka (UNN), and were maintained on a commercial feed (grower's marsh) for about one week in the laboratory before commencing the experiment. Sixty animals were divided into three groups, based on their ages as newly weaned rats (NWR), middle-aged rats (MAR) and aged rats (AR), of five rats per cage.

The animals were fed ad libitum for about two months with the insecticide contaminated diets, except the controls for each group. They were provided with adequate water supply daily.

\section{Total protein determination}

Total protein in blood plasma was assayed for by a modified Lowry method with FolinCiocalteau reagent as described by Cunha- 
Bastos et al. ${ }^{11}$. Bovine serum albumen (B.S.A) was used as standard protein.

\section{Superoxide Dismutase Assay}

An indirect method of inhibiting auto-oxidation of epinephrine to its adrenochrome was used to assay SOD activities in blood plasma ${ }^{12}$. Autooxidation of epinephrine was initiated by adding $1 \mathrm{ml}$ of Fenton reagent prepared as described by Onwurah $^{13}$. To a mixture of epinephrine $\left(3 \times 10^{-4}\right.$ $\mathrm{M}), \mathrm{Na}_{2} \mathrm{CO}_{3}\left(10^{-3} \mathrm{M}\right)$, EDTA $\left(10^{-4} \mathrm{M}\right)$, and $1.0 \mathrm{ml}$ of deionised water at a final volume of $6 \mathrm{ml}$. The auto-oxidation was read in a spectrophotometer at $480 \mathrm{~nm}$ every $30 \mathrm{sec}$ for $5 \mathrm{~min}$. The experiment was repeated with $1.0 \mathrm{ml}$ of the blood plasma from blood samples collected from different groups of experimental animals. A graph of absorbance against time was plotted for each, and the initial rate of auto-oxidation calculated. One unit of SOD activity was defined as the concentration of the enzyme (mg protein $/ \mathrm{ml}$ ) in the plasma that caused $50 \%$ reduction in the auto-oxidation of epinephrine ${ }^{14}$. Superoxide dismutase activity was subsequently calculated for each sample.

\section{RESULTS}

Table 1 show the results of inhibition studies on the auto-oxidation of epinephrine by blood plasma protein of rats exposed to "Rambo" insecticide-contaminated diet at various concentrations of $1 \%, 5 \%$ and $10 \%$ (w/w). Plasma protein and SOD specific activity is shown in Table 2.

The result show that there was a decrease in the plasma protein level within the groups NWR, MAR and AR of experimental rats but this decrease was not significantly different $(\mathrm{P}>$ 0.05) when compared with the parallel control group.

The specific activity of SOD did not significantly increase in the NWR groups fed with $1 \%, 5 \%$ and $10 \%(\mathrm{w} / \mathrm{w})$ - contaminated diet relative to control $(\mathrm{P}>0.05)$. In the contrary, the MAR groups and AR groups fed with $1 \%, 5 \%$ and $10 \%$ - contaminated diets respectively showed significant increase in the

TABLE 1: Rate of auto-oxidation of epinephrine in rats exposed to insecticide-contaminated diet

\begin{tabular}{|c|c|c|}
\hline Auto-oxidation mixtures (Am) & $\begin{array}{l}\text { Auto-oxidation rate } \\
\text { (Units/min) }\end{array}$ & Percent inhibition (\%) \\
\hline $\mathrm{Am}+1.0 \mathrm{ml}$ Distilled $\mathrm{H}_{2} \mathrm{O}$ & $0.078 \pm 0.003$ & -- \\
\hline $\mathrm{Am}+1.0 \mathrm{ml}$ plasma NWR $1 \% *$ & $0.026 \pm 0.014$ & $66.67 \pm 0.047$ \\
\hline $\mathrm{Am}+1.0 \mathrm{ml}$ plasma NWR $5 \%$ & $0.073 \pm 0.047$ & $6.41 \pm 0.047$ \\
\hline $\mathrm{Am}+1.0 \mathrm{ml}$ plasma NWR $10 \%$ & $0.037 \pm 0.013$ & $52.56 \pm 0.013$ \\
\hline $\mathrm{Am}+1.0 \mathrm{ml}$ plasma NWR control & $0.070 \pm 0.030$ & $10.26 \pm 0.044$ \\
\hline $\mathrm{Am}+1.0 \mathrm{ml}$ plasma MAR $1 \%$ & $0.066 \pm 0.044$ & $15.38 \pm 0.044$ \\
\hline $\mathrm{Am}+1.0 \mathrm{ml}$ plasma MAR $5 \%$ & $0.047 \pm 0.003$ & $57.69 \pm 0.003$ \\
\hline $\mathrm{Am}+1.0 \mathrm{ml}$ plasma MAR $10 \%$ & $0.066 \pm 0.044$ & $15.38 \pm 0.044$ \\
\hline $\mathrm{Am}+1.0 \mathrm{ml}$ plasma MAR control & $0.033 \pm 0.003$ & $57.38 \pm 0.003$ \\
\hline $\mathrm{Am}+1.0 \mathrm{ml}$ plasma AR $1 \%$ & $0 . .021 \pm 0.010$ & $26.92 \pm 0.032$ \\
\hline $\mathrm{Am}+1.0 \mathrm{ml}$ plasma AR $5 \%$ & $0.042 \pm 0.019$ & $46.15 \pm 0.019$ \\
\hline $\mathrm{Am}+1.0 \mathrm{ml}$ plasma AR $10 \%$ & $0.048 \pm 0.023$ & $38.46 \pm 0.023$ \\
\hline $\mathrm{Am}+1.0 \mathrm{ml}$ plasma AR control & $0.030 \pm 0.010$ & $61.54 \pm 0.010$ \\
\hline
\end{tabular}

* Plasma taken from different groups of rats eg. Newly weaned rats (NWR) fed with $1 \%(w / w)$ contaminated diet. For details see materials and method. 
TABLE 2: SOD activity and total plasma protein levels in rats exposed to insecticide-contaminated diets

\begin{tabular}{l|lll}
\hline GROUP & $\begin{array}{c}\text { Plasma total } \\
\text { protein } \\
(\mathbf{m g} / \mathbf{m l})\end{array}$ & \multicolumn{2}{c}{ Superoxide dismutse (SOD) } \\
\cline { 3 - 4 } & $0.66 \pm 0.14$ & $\begin{array}{l}\text { Activity } \\
\left.\text { (units }^{a} / \mathbf{m l}\right)\end{array}$ & $\begin{array}{l}* \text { Specific activity } \\
\text { Unit/mg protein }\end{array}$ \\
NWR 1 \% & $0.33 \pm 0.0003$ & $2.02 \pm 0.34$ \\
$\quad$ NWR 5\% & $0.64 \pm 0.17$ & $0.13 \pm 0.0009$ & $0.20 \pm 0.26$ \\
NWR 10\% & $0.48 \pm 0.04$ & $1.05 \pm 0.0003$ & $2.19 \pm 0.29$ \\
NWR control & $0.43 \pm 0.02$ & $0.21 \pm 0.0006$ & $0.49 \pm 0.11$ \\
$\quad$ MAR 1\% & $0.56 \pm 0.11$ & $0.31 \pm 0.0009$ & $0.55 \pm 0.13$ \\
MAR 5\% & $0.68 \pm 0.22$ & $0.80 \pm 0.0006$ & $0.18 \pm 0.10$ \\
MAR 10\% & $0.65 \pm 0.18$ & $0.31 \pm 0.0009$ & $0.48 \pm 0.17$ \\
MAR control & $0.67 \pm 0.19$ & $1.15 \pm 0.0006$ & $1.72 \pm 0.24$ \\
AR 1 \% & $0.52 \pm 0.08$ & $0.23 \pm 0.0008$ & $0.44 \pm 0.15$ \\
AR 5\% & $0.47 \pm 0.05$ & $0.92 \pm 0.0004$ & $1.96 \pm 0.23$ \\
AR 10\% & $0.41 \pm 0.01$ & $0.77 \pm 0.0005$ & $1.88 \pm 0.18$ \\
AR control & $0.56 \pm 0.07$ & $1.23 \pm 0.0002$ & $2.20 \pm 0.45$ \\
\hline
\end{tabular}

*Specific activity for the SOD in all the groups is not significantly different $(P<$ 0.05)

${ }^{a}$ One unit (of activity) of Sod is generally define as the amount of the enzyme that inhibits the autoxidation (of epinephrine) by $50 \%$.

Table 3: Duncan multiple range test of oneway ANOVA for comparing the ages of rats exposed to varying concentrations of insecticide-contaminated diet on SOD activity

\begin{tabular}{|l|l|l|}
\hline COMBINATIONS & \multicolumn{2}{c|}{ SOD IN PLASMA } \\
\hline \multicolumn{1}{|l|}{} & $\begin{array}{l}\text { DIFFERENC } \\
\text { E }\end{array}$ & L.S.R \\
\hline NWR 1\%/ MAR 1\% & 0.043 & 0.162 \\
\hline NWR 1\%/ AR 1\% & 0.003 & 0.162 \\
\hline AR1\% / MAR 1\% & 0.043 & 0.162 \\
\hline NWR 5\%/ MAR 5\% & 0.026 & 0.130 \\
\hline NWR 5\%/ AR 5\% & 0.005 & 0.130 \\
\hline AR 5\% / MAR 5\% & 0.031 & 0.130 \\
\hline NWR 10\%/ MAR 10\% & 0.037 & $-0.049 *$ \\
\hline NWR 10\%/ AR 10\% & 0.000 & $-0.049 *$ \\
\hline AR 10\% / MAR 10\% & 0.037 & $-0.049 *$ \\
\hline
\end{tabular}

*Significantly different result $(p<0.05)$ specific activity of SOD $(p<0.05)$ relative to their controls. Pair wise comparison between NWR/MAR, NWR/AR and MAR/AR groups, fed with $1 \%, 5 \%$ and $10 \%(\mathrm{w} / \mathrm{w})$ insecticide contaminated diet between $7-21$ days of exposure showed significantly different results $(\mathrm{P}<0.05)$ on SOD only at $10 \%(\mathrm{w} / \mathrm{w})$ insecticide -contaminated diet; but the $1 \%$ and $5 \%(\mathrm{w} / \mathrm{w})$ insecticide - contaminated showed non significant difference $(\mathrm{P}>0.05)$ (Table 3$)$.

The mortality result shows that NWR recorded the death of only one rat while AR showed four rats. Generally, no case of littering was recorded all through the experimental groups when compared with the parallel control groups.

\section{Statistical analysis}

Mean values $( \pm S D)$ of duplicate experiment with duplicate sampling $(\mathrm{N}=4)$ were taken for each analysis. A significantly different result was established by one-way ANOVA and differences 
between groups by Duncan multiple range test. The accepted level of significance was $p<0.05^{15}$.

\section{DISCUSSION}

Pesticides are toxic substances by nature. They are manufactured with the intent to kill or control pests, but many problems are related to their use. During application, they may contaminate food or bioaccumulate in crops or food chain, causing liver damage or become carcinogenic in animals after uptake ${ }^{16}$. The oxidations of pesticides in vivo involve several possibilities, which include the formation of reactive oxygen species, $\mathrm{ROS}^{4}$. Reactive oxygen species are highly damaging to biological tissues and their generation appears to be important mode of action for a variety of environmental contaminants including pesticides.

The results of this study highlight the potential susceptibility of exposed organisms especially non-target animals to toxic injury as a result of intake of the 'Rambo' insecticide via contaminated food There was a decrease in the level of plasma protein in the rats exposed to different concentrations of the insecticide for NWR, MAR or AR group when compared with their parallel control groups of rats fed with uncontaminated diet. Thus, the reduction in total plasma protein in these groups of experimental animals may be due to the formation of high protein carbonyl derivatives as a result of free radical attack on the cell proteins. This agreed with the earlier work reported by Onwurah ${ }^{13}$, who suggested that there was relatively low level of protein in the cells of Azotobacter vinelandii, exposed to different concentrations of environmental contaminants. Similarly, Schuppe et al., ${ }^{17}$, showed that during lipid peroxidation and glutathione depletion, proteins are exposed to a wide range of free radical species capable of oxidizing protein thiols, thus promoting the formation of disulphide bridges and even induction of protein fragmentation and catabolism. All the above will affect normal protein metabolism and growth and thus may result in body weight loss.

Oxidation of membrane-associated proteins may also occur during lipid oxidation. The overall consequence is breakdown in membrane integrity and membrane dependent functions ${ }^{18}$. Damage to such membrane - associated protein may originate directly from reactions with oxygen radicals or from reaction with lipid peroxides and/or their decomposition products ${ }^{19}$. The observed low levels of plasma protein were attributed to protein oxidation and catabolism as a result of the toxicant (Rambo insect powder) in the food. In normal tissue, there is a balance between the production and scavenging of reactive oxygen metabolites (ROMS). According to $\mathrm{Sies}^{20}$, oxidative stress occurs when the rate of cellular antioxidant depletion exceeds the rate of replacement. The consequence of such is tissue damage and may lead to cell death ${ }^{21}$. Antioxidant systems are normally put in place in living aerobic organisms to counter the effect of oxidative stress $^{22}$. The results of this work showed that SOD activity increased significantly in the MAR and AR groups while the NWR groups did not show a significant increase in the SOD activity relative to their parallel controls. The differences in the plasma SOD levels particularly may be due to some factors, such as age, sex, concentration of toxicant e.t.c. The increase in SOD activity in the groups NWR, MAR and AR was attributed to an induction of the enzyme protein in the presence of reactive metabolites of Rambo insect powder (containing $0.6 \%$ permethrin). This agreed with the earlier work done by Ledig and Doffoel ${ }^{6}$, who reported an increase in SOD activity in erythrocytes of alcoholic patients. The increase in enzyme activity at an earlier stage in life may suggest that NWR groups have the capacity of increasing the level of SOD activity and thus were able to overcome the oxidative stress induced thereof. Such event has been reported for microorganisms exposed to crude oil and Fenton reagent ${ }^{4}$. The induction in SOD activity in rats' blood plasma when exposed to environmental toxicants such as Rambo insecticide may be an adaptive mechanism for survival. The rate at which individual and or groups of rats metabolized the toxicant is agedependent. This is justified by the mortality ratio (1:4) for NWR and AR groups exposed to 5\% and $10 \%(\mathrm{w} / \mathrm{w})$ contaminated diet. Delayed reproduction in the exposed rats was observed 
compared to controls because no case of littering in any of the groups throughout the experimental period was recorded. However three months later, the animals' reproductive ability was reactivated as littering occurred among the three groups NWR, MAR and AR. "Rambo" insect powder contains $0.6 \%$ permethrin, (pyrethroid compound) as its active ingredient (according to the manufacturer). Therefore toxicity of the pyrethroid insecticides such as deltamethrim, cypermethrim, zeta-cypermethrin may follow the same pattern as permethrin. Pyrethroids have been implicated in causing neurotoxicity and liver enlargement, skin and eye irritation, suppression of immune and reproductive systems, and this may also be the case for individuals exposed to sub - chronic doses of Rambo insecticide.

\section{Conclusion}

The data presented in this study revealed that the induction of SOD in rats exposed to Rambo contaminated diet could be an adaptive mechanism by which non-target organisms survived the toxic effect of the pesticide. However, prolonged exposure may overwhelm the activity of SOD and consequently elicit different health effects or even death of nontarget organisms including humans.

\section{REFERENCES}

1. Bhatia, A. and Kaur, J. (2000) Evaluation of hematological and immunological Parameters in Mice Exposed to sub-lethal and sub-chronic doses of dimethoate. Tox. Subst. Mechanism 19: 99 - 109.

2. Morrison, H., Savitz, D., Semencior, R., Hulka, B., Mao, Y., Morrison, D., and Wigle, D. (1993) Farming and prostrate cancer mortality. Am. J. Epidemol. 137:270-280.

3. Weisenburger, D.D. (1993) Human health effects of agrochemical use. Hum. Pathol. 24:571 - 576 .

4. Onwurah I. N. E. and Eze M. O. (2000) Superoxide dismutase activity in Azotobacter vinelandii in the disposition of environmental toxicants exemplified by Fenton reagent and crude oil. J. Tox. Subst. Mech. 19: 111 - 123.
5. Bridges, J. W., Benford D. J., and Hubbard S. A. (1983) Mechanisms of toxic Injury. Annals of New York Academy of Sciences. 83: $42-63$.

6. Ledig M. and Doffoel M. (1988) Superoxide dismutase activity in erythrocytes of alcoholic patients. $A d v$. Biosciences 71:125-129.

7. Olusi, S. O., (2002) Obesity is an independent risk factor for plasma lipid peroxidation and depletion of erythrocyte cytoprotective enzymes in humans. Intl. J.Obesity. 26: 1159-1164.

8. Chen CN. And Pan SM. (1996) Assay of Superoxide Dismutase activity by combining electroporesis and densitometry. Bot. Bull. Acad. Sin. 37: $107-111$.

9. Brennan, L.A., Morris, G.M., Wasson, G.R., Hannigan, B.M. and Barnett, Y.A (2000) The effect of vitamin $C$ or vitamin E supplementation on basal and $\mathrm{H}_{2} \mathrm{O}_{2}$ induced DNA damage in human lymphocytes. Brit. J.Nutr. 84 (2).

10. Worthin, C.R., and Walker, S.B. (1983) The pesticide manual. A world compendium. London: British Crop Protection Council.

11. Cunha-Bastos, V. L. T., Cunha-Bastos, J., Lima J. S., and Castro-Faira, M. V. (1991) Brain acetylcholinesterase as an "in-vitro" detector of organophosphorus and carbamate insecticide in water. Water Resouces. 25:835-840.

12. Misra, H. P. and Fridovich, I. (1971) The generation of superoxide radical during the autoxidation of ferridoxin. $J$. Biol.Chem. 246:6886-6890.

13. Onwurah I.N.E (1999) Lipid peroxidation and protein oxidation in Azotobacter vinelandii exposed to mercury, silver crude oil and Fenton reagent. J. Tox. Substs. Mech. 18:167-176

14. Jewett, S. L. and Rocklin, A. M. (1993) Variation in one unit of activity with oxidation rate of organic substrate in indirect superoxide dismutase assays. Anal. Rev. Biochem. 212: 55 - 59.

15. Duncan,D. (1955) Multiple range test and multiple F-tests. Biometrics. 11: 1 - 42. 
16. Chaudhuri, K., Salvaraj, S. and Pal, A.K. (1999) Studies on the genotoxicity of endosulfan in bacteria systems. Mutat. Res. 439: $63-67$.

17. Schuppe, I., Moldons, P.I. and Cotgreave, I. (1992) Protein specific S-thiolation in human endothelia cells during oxidation stress. Biochem. Pharmacol. 44: 1757 164.

18. Konat, G. and Wiggins, R.C. (1985) Effect of reactive Oxygen Species on Myelin Membrane Proteins. J. Neurochem. 45:1113-1118.

19. Divakaran, P. and Wiggins, R.C. (1987) Tocopherol in brain metabolism and disease. Metab. Brain. Dis. 2:1-12.
20. Sies, H. (1997) Oxidation stress: oxidants and antioxidants. Exp. Physiol. 82:291195.

21. Nwaguma, B.C. Achebe, A.C. Ezeanyika, L.U.S. and Eze, L.C. (1999) Toxicity of oxidized fats II: Tissue levels of lipid peroxides in rats fed by a thermally oxidized corn oil diet. Food and Chem. Tox. 37:413-416.

22. Elstner, E.F. and Osswald, W. (1994) Mechanism of Oxygen activation during plant stress. Proc. R. Soc. Edinb Sect. B. 102:131-154. 